\title{
Escola livre de dança da Maré: um chão em partilha
}

\author{
Adriana Pavlova ${ }^{1}$ e Silvia Soter ${ }^{2}$ \\ Resumo: O artigo trata da experiência da Escola Livre de Dança da Maré, criada pela artista Lia Rodrigues e \\ pela professora Silvia Soter em parceria com a Redes de Desenvolvimento da Maré. A formação em dança \\ de jovens estudantes tem impacto para além de uma formação técnica e profissional, abrindo possibilidades \\ de futuro e alargando subjetividades.
}

Palavras-chave: ensino de dança. dança. favela. jovens.

\section{Free School of Dance at Maré: A Ground to Share}

\begin{abstract}
This paper discusses the experience of the Maré Free Dance School), created by artist Lia Rodrigues and professor Silvia Soter in partnership with the NGO Redes de Desenvolvimento da Maré. The dance training developed has an impact beyond technical and professional training for the young students, opening up new future possibilities and widening subjectivities.
\end{abstract}

Keywords: dance teaching. dance. favela. youth.

1 Jornalista, crítica de dança do jornal O Globo, doutoranda em Literatura, Cultura e Contemporaneidade no PPGLCC da PUC-Rio. Mestre em Artes da Cena pelo PPGAC da Escola de Comunicação da UFRJ (2015). Bacharel em Comunicação Social pela UFF (1992). Vínculo institucional: Pontifícia Universidade Católica do Rio de Janeiro, Rua Marques de São Vicente, Gávea - Rio de Janeiro, RJ, 22452-900. E-mail: adripavlova@gmail.com. ORCID: https:// orcid.org/0000-0002-3559-2291. Lattes iD: http://lattes.cnpq.br/0100711332820288. Rio de Janeiro, Brasil.

2 Professora da Faculdade de Educação da UFRJ e do Programa de Pós Graduação em Dança da UFRJ (PPGDAN). Doutora em Educação pela UFRJ, mestre em Teatro pela UNIRIO (2005), licenciada em Dança pela Universidade de Paris 8 (França/1996) e bacharel em Artes pela PUC-Rio (1988). Vínculo institucional: Faculdade de Educação da Universidade Federal do Rio de Janeiro, Av. Pasteur, 250, Urca - Rio de Janeiro, RJ, 22290-240. E-mail: ssotersilvia@ gmail.com. ORCID: https://orcid.org/0000-0002-9760-8551. Lattes iD: http://lattes.cnpq/1863257735933617. Rio de Janeiro, Brasil. 
Em 2004, a coreógrafa Lia Rodrigues fez um movimento transformador na sua trajetória artística: deixou a Zona Sul, região mais rica do Rio de Janeiro, Brasil, onde trabalhara a maior parte do tempo desde a fundação de sua companhia, em 1990, para uma residência no Complexo de Favelas da Maré3, Zona Norte. Desde 2009, já em parceria com a Redes de Desenvolvimento da Maré, a Lia Rodrigues Companhia de Danças - LRCD passou a ter uma sede própria, em Nova Holanda, uma das comunidades deste complexo de favelas: o Centro de Artes da Maré - CAM, local de ensaio, criação e apresentação das peças da companhia. É neste lugar, por exemplo, que aconteceram as estreias nacionais e as temporadas de suas últimas criações, Pororoca (2009), Piracema (2011), Pindorama (2013) e Para que o céu não caia (2016) 5 .

Desde 2011, o CAM também abriga a Escola Livre de Dança da Maré ELDM, fruto do projeto da companhia com a Redes de Desenvolvimento da Maré. É neste mesmo espaço que, a partir de 2012, acontecem as aulas e ensaios diários do Núcleo 2, projeto de formação técnico, artístico e profissional com jovens da Maré e de outras regiões, idealizado pela coreógrafa ao lado da dramaturgista da companhia, a professora Silvia Soter, responsável pelo convite para a transferência de Lia Rodrigues e sua equipe para a favela em 2004. O Núcleo 2 é o principal elo da companhia com a ELDM.

A escolha de uma favela como lugar para o trabalho regular de uma companhia profissional de dança contemporânea vai ao encontro de uma nova forma de dar visibilidade às comunidades populares, respondendo à provocação dos geógrafos Jorge Barbosa e Jailson de Souza e Silva, que defendem a "construção de uma outra representação das favelas - para além das ausências mais visíveis".

3 Maré é um conjunto de 16 favelas onde habitam cerca de 140 mil pessoas, distribuídas ao longo do trecho que vai do Caju até Ramos, pela Avenida Brasil, via de circulação que une o Centro e as áreas periféricas da Zona Oeste da cidade do Rio de Janeiro. Sua formação remonta a um longo processo de mudanças urbanas que atingiu a cidade, especialmente na segunda metade do século XX. (Silva, 2012, p.61).

4 A transferência da companhia de Lia Rodrigues para a Maré se deu, em 2004, com o apoio da ONG Centro de Estudos e Ações Solidárias da Maré (CEASM), cuja diretoria se dividiu em 2007, dando origem à Redes de Desenvolvimento da Maré, Organização da Sociedade Civil de Interesse Público (Oscip), que a partir daí tornou-se a nova parceira de Lia Rodrigues.

5 Fúria, trabalho mais recente da companhia, teve sua estreia mundial em 30 de novembro de 2018 em Paris e ainda não foi apresentada na CAM. 
A residência na favela não é uma experiência isolada na trajetória de Lia Rodrigues. Desde que se estabeleceu no Rio de Janeiro, nos anos 1980, a coreógrafa paulistana fez parte de um time de criadores que pensava a dança para além da questão artística, ou ainda, para além de uma visão que dissocia o político do artístico. Sua geração foi fundamental para o estabelecimento de um cenário positivo para a dança contemporânea na década de 1990: conquista de políticas públicas específicas e inéditas para a área ${ }^{6}$ foram implantadas pela Prefeitura; surgiram festivais, entre eles o Panorama, o último criado e dirigido por Lia Rodrigues, durante mais de uma década e que se manteve anualmente até 2018. Durante muitos anos, a coreógrafa foi portavoz da classe da dança, fazendo, muitas vezes, a intermediação entre artistas e poder público. A chegada de Lia Rodrigues e dançarinos à Maré, em 2004, foi uma decisão decorrente das reflexões desta artista sobre formas de produzir dança e de fazer arte. Desde o início de sua trajetória, Lia Rodrigues busca alargar suas possibilidades de agir no mundo, para além da criação coreográfica propriamente dita, interrogando-se sobre o chão em que quer dançar (Lepecki, 2012). Essa inquietação marca sua obra coreográfica. Assim ela justificou a mudança para a Maré:

\begin{abstract}
A ideia era fazer uma residência e ver o que aconteceria depois de estar lá, como iria se desdobrar. Eu sou uma pessoa que faço projetos. Fiz um festival durante 14 anos e antes sempre me envolvi nas questões sobre as condições de trabaIho em dança. Desde que comecei a trabalhar, em 1976, sempre me envolvi no pensamento sobre como se sobrevive com dança, como se dança, para quem se dança. Tudo é desdobramento dessas perguntas. A ida para Maré está na ordem do fazer, de experimentar alguma coisa diferente." ${ }^{7}$
\end{abstract}

O pesquisador André Lepecki defende a ideia de coreopolítica como um campo expandido da dança. Trata-se, segundo ele, de uma atividade particular e imanente de ação, cujo principal objeto é aquilo que Paul Carter chamou de "política do chão". A partir do conceito de Carter, autor que trata das relações entre a representação das artes no Ocidente e as bases filosóficas, políticas, cinéticas e raciais

6 Na primeira metade dos anos 2000 , as políticas públicas específicas para dança no Rio de Janeiro foram sendo descontinuadas.

7 Entrevista feita por Skype, em 16/12/2014. 
do colonialismo. Lepecki afirma que "uma política coreográfica do chão atentaria à maneira como coreografias determinam os modos como danças fincam seus pés nos chãos que as sustentam; e como diferentes chãos sustentam diferentes danças transformando-as, mas também se transformando no processo". Haveria, assim, uma "corressonância coconstitutiva [...] entre danças e seus lugares; e entre lugares e suas danças". Ele afirma:

Para Carter, a política do chão não é mais do que isto: um atentar agudo às particularidades físicas de todos os elementos de uma situação, sabendo que essas particularidades se coformatam num plano de composição entre corpo e chão chamado história. ${ }^{9}$

Segundo Lepecki, o entendimento de chão para Carter vai além de uma categoria metafísica. Carter propõe que o chão seja visto como a própria entidade física e material que ele é. Ele pede que o chão seja entendido teoricamente não como uma "superfície abstrata mas como superfícies de múltiplas camadas, cujas diferentes amplitudes compõem um ambiente [...] único, local, que não pode ser transposto. ${ }^{10} 11$

Lepecki defende que uma política do chão está relacionada, antes de mais nada, à crença de um chão como um terreno repleto de histórias, de altos e baixos, rugas, valas, quebras, sulcos, que ganha ainda outras camadas ao se encontrar com novos corpos, novas histórias igualmente multifacetadas. Neste sentido, para Lepecki, "toda coreopolítica revela o entrelaçamento profundo entre movimento, corpo e lugar"12. Entrelaçamento este que é constitutivo do trabalho de Lia Rodrigues e que ganha ainda mais contornos a partir da mudança de sua companhia para a Maré. ${ }^{13}$

8 Lepecki, 2012, p.47.

9 Idem.

10 Carter, apud Lepecki, 2006, p.99.

11 No original, "Carter ties the question of colonialism to the question of representation, to the question of ontology, and to the notion of the ground. For Carter, this ground should be understood not only as a metaphysical category but also as the very physical material entity that it is. He asks for the ground to be theoretically grasped not as an abstract 'surface but as manifold surfaces, their different amplitudes composing an environment [...] uniquely local, which could not be transposed".

12 Lepecki, 2012, p.55

13 Ver Pavlova 2015. 


\section{Dimensão formadora da companhia}

A coreógrafa costuma enfatizar, em inúmeras entrevistas, a dimensão de formação de artistas dentro do trabalho que realiza em sua companhia de dança. O fato de contar, muitas vezes, com intérpretes jovens e com pouca experiência prévia em companhias profissionais como membros da LRCD tem feito com que os processos de criação de suas obras ganhem uma dimensão de formação desses intérpretes. Formação é entendida aqui como um processo em que se conjugam estratégias de ensino-aprendizagem, nem sempre formalizadas, e troca de saberes entre a própria coreógrafa, outros artistas, professores convidados e os integrantes da companhia. Muitos artistas da dança, após alguns anos como colaboradores da LRCD, partiram para projetos próprios como criadores-intérpretes, munidos de saberes e de competências que desenvolveram nesses anos de trabalho na companhia. Uma rotina que inclui a participação diária em aulas de dança e de abordagens corporais, a colaboração nos processos de criação de espetáculos, o aprendizado de obras do repertório da companhia, em ensaios diários e turnês nacionais e internacionais. Também nos últimos 15 anos, junto com os artistas de sua companhia ou sozinha, Lia Rodrigues tem ministrado workshops, aulas e cursos de curta ou média duração.

Consciente do potencial de formação de jovens artistas de sua companhia ao longo dos anos, Lia Rodrigues decidiu criar a Escola Livre de Dança da Maré, em parceria com a Redes de Desenvolvimento da Maré que, por sua vez, viu na aproximação com a artista a possibilidade de construir um projeto consistente de ensino de dança, acessível aos moradores da Maré, lugar que apesar de ter população residente de quase 140 mil pessoas não possuía um espaço dedicado ao ensino da dança. Em 2014, numa conversa aberta ao público no CAM, Lia Rodrigues fez uma análise deste aspecto de formação de sua companhia, que, segundo ela, acabou influenciando a criação da Escola Livre de Dança da Maré e o surgimento do Núcleo 2. A coreógrafa explicou:

Fui me dando conta que as pessoas que entravam na companhia, eu e elas aprendíamos juntos. Aqueles meninos que trabalhavam comigo desabrochavam como artistas. A gente trabalha muitas horas por dia, sete horas por dia, faz aulas diferentes e, de repente, vê esse processo de desabrochar. Percebi que muitos meninos que trabalharam comigo viraram artistas com outras ideias, procuraram seus rumos. Percebi que de alguma forma o meu trabalho como criadora estava ligado à formação, e daí veio a ideia da escola [...] e a gente começou a desenhar essa escola que agora está funcionando. [...] Às vezes, tenho que dar aula para 
eles, fico nervosa, a gente faz uma aula de conversa, senta numa mesa, deixa à deriva para surgirem questões e a gente vai discutindo essas questões. Não dou uma técnica em si, mas eu procuro trabalhar junto, estimular a criatividade. ${ }^{14}$

A Escola Livre de Dança da Maré, cujas as atividades diárias e regulares são frequentadas, em média, por 300 alunos desde sua inauguração constituise como um dos projetos centrais do Centro de Artes da Maré. Além de oficinas de dança gratuitas e abertas a todos, a escola realiza um importante trabalho, desde 2012, com um conjunto de jovens selecionados através de audições que frequentam aulas e oficinas, em diálogo direto com a Lia Rodrigues Companhia de Danças. Esta turma, conhecida como Núcleo 2 , recebe mais do que um treinamento técnico em dança, já que a ênfase deste braço da escola é a formação em dança como linguagem artística, articulada à criação contemporânea. O Núcleo 2, chamado assim porque as demais aulas abertas ao público configuram o Núcleo $1^{15}$, se constitui como materialização das ações de formação de artistas de Lia Rodrigues e de sua companhia. É a coreógrafa que, junto com Silvia Soter, coordenadora pedagógica da ELDM, quem planeja todas as atividades deste grupo. $\mathrm{O}$ conjunto de propostas que têm composto o trabalho do Núcleo 2 inclui aulas regulares de dança contemporânea e de balé clássico, workshops com artistas convidados, participação em processos de remontagem de peças de dança e mergulho no repertório da LRCD. As vinte horas de aulas semanais do Núcleo 2 acontecem de segunda a sexta-feira, na parte da tarde.

\section{Lia Rodrigues, uma 'pedagoga construtora'}

É possível associar Lia Rodrigues à categoria dos "pedagogos construtores", proposta por Chopin $(2015)^{16}$. Chopin identificou quatro perfis principais de pedagogos da dança: o "passador" (le passeur), o inovador (le nova-

\footnotetext{
14 A história da LRCD registra uma clara tendência à formação de coreógrafos, mesmo sem nenhuma sistematização concreta dessa preocupação. Muitas das artistas que participaram da primeira década da companhia saíram para desenvolverem trabalhos pessoais. Caso de Denise Stutz, Duda Maia, Marcela Levi e Micheline Torres, em ação na dança carioca, nacional e internacional. O mesmo aconteceria, nos anos 2000, com Claudia Muller, Jamil Cardoso, Celina Portella e Volmir Cordeiro, dentre outros. A companhia foi, portanto, incubadora relevantes artistas da cena contemporânea.

15 São aulas de dança contemporânea, dança urbana, consciência corporal, danças afro-brasileiras, dança de salão e balé.

16 A partir da análise dos verbetes do dicionário Larousse de Dança (2008), que traziam artistas da dança que de modos distintos se aproximaram da pedagogia, se interessaram pela dimensão pedagógica da dança. Alguns desses artistas tiveram a pedagogia como atribuição principal, outros como atribuição acessória, em um caso como no outro, Chopin os designa pedagogos da dança.
} 
teur), o construtor (le bâtisseur) e o teórico (le theoricien) ${ }^{17}$. As categorias constituídas por Chopin não são necessariamente excludentes, um mesmo pedagogo pode ser identificado como inovador e construtor ao mesmo tempo, por exemplo.

Pela classificação de Chopin, são entendidos como "passadores" os pedagogos que têm ou tiveram como função principal transmitir um modo específico de dança, no caso deles, passar para a frente aquilo que receberam de outrem, de um mestre, de uma escola, de um outro artista. É o fato de provocar uma ruptura no universo coreográfico que o antecede que caracteriza o pedagogo inovador. Diferente do passador, o inovador não é depositário do saber de um mestre, nem fiel ao passado ou à tradição. O pedagogo inovador, na maior parte dos casos, é também coreógrafo e, como artista, inaugura modos próprios de abordagem da dança em suas criações. O caráter inovador desses artistas requer, por sua vez, que estes desenvolvam caminhos pedagógicos próprios, uma vez que "abrir uma nova via para a arte implica em dar meios para que esta seja percorrida"18. No conjunto dos pedagogos teóricos estão aqueles que desenvolveram saberes, os organizaram em teorias próprias e que aperfeiçoaram modos também próprios para colocá-las em ação, ou a partir de formas de observação e leitura do movimento dançado ou de experimentação deste.

Já o pedagogo construtor é aquele que constrói situações e espaços para que a dança possa se introduzir e se desenvolver. A escolha de um termo relativo à área da construção civil para caracterizar este perfil se justifica exatamente por este tipo de pedagogo concretizar novos lugares e novas possibilidades para a dança existir e se desenvolver. $O$ pedagogo construtor

conquista novos territórios para permitir que a dança exista como instituição: escolas, centros coreográficos, festivais ou concursos. Sua atividade visa a construção de telas estruturais sobre as quais poderão se inscrever as formas coreográficas que compõem o universo da dança. ${ }^{19}$

17 Chopin, 2015, p. 56.

18 Chopin, 2015, p. 64. No original, "ouvrir une nouvelle voie pour l'art implique de donner les moyens de la rendre empruntable."

19 Chopin, 2015, p. 74. No original: “(...) conquiert de noveaux territoires pour permettre à la danse d'exister en tant qu'instituition: écoles, centres choregraphiques, festivals ou concours. Son activité vise la construction de canevas structurels sur lesquels vont pouvoir s'inscrire les formes choregraphiques composant l'univers de la danse." 
A atividade do pedagogo construtor pode ser ou mais dirigida à criação de estruturas para a dança, como centros e escolas de formação e difusão, ou mais orientada para os aspectos políticos, "remetendo à maneira como o espaço coreográfico consegue se impor sobre outras cenas (sociais, evidentemente, mas também universitárias, científicas e mediáticas)"20.

Situar Lia Rodrigues na categoria de pedagogo construtor não significa considerar que a coreógrafa tenha a atividade pedagógica como eixo de sua atuação profissional. Chopin considera como pedagogos da dança também artistas cuja identidade principal não é a de professor de dança ou maître de ballet e, sim, de criadores, caso de Lia Rodrigues, que assim define o Núcleo 2:

O Núcleo 2 é uma experiência pedagógica juntando a minha vontade de partilhar com a da Silvia [Soter], um encontro num projeto de formação continuada que me dá intensa alegria e também muita preocupação. É uma luta diária, porque estamos pensando o tempo todo em como lidar com questões de ordem prática, como as faltas. É um desafio, não é só uma formação de dança, fazer aula, é para a vida deles. Nem sempre é tudo ótimo, tudo bacana, mas, ao mesmo tempo, é lindo vê-los trabaIhando, já tão amadurecidos. ${ }^{21}$

\section{Metodologia mutante como marca do Núcleo 2}

Em sua formação do primeiro semestre de 2018, o Núcleo 2 contava com dez alunos veteranos - dos quais, quatro mulheres e seis homens, com idades variando entre 19 e 27 anos - além de seis novos alunos que fizeram audição em setembro de $2017^{22}$. Os veteranos, todos de famílias de baixa renda, recebiam uma pequena ajuda de custo para cobrir o transporte e para que pudessem se dedicar à dança por tantas horas por semana. Também 2018, o último dos dez conseguiu ingressar na universidade pública: oito cursavam dança na Universidade Federal do Rio de Janeiro, en-

20 Chopin, 2015, p. 74. No original: "renvoyant à la manière dont l'espace choregraphique parvient à s'imposer sur d'autres scènes (sociales bien sûr mais aussi universitaires, scientifiques, médiatiques, etc.)"

21 Entrevista concedida em 9/10/2015.

22 O núcleo dos veteranos começou a ser desfeito em meados de 2018, quando quatro dos dez jovens foram convidados por Lia Rodrigues para participar de Fúria, trabalho de sua companhia que estreou na França em novembro de 2018. Nos segundo semestre de 2018, os outros seis jovens começaram o processo de desligamento, dando aulas para os novos dançarinos, selecionados numa audição em agosto de 2018. Em julho de 2020, o Núcleo 2 é formado por 15 jovens. 
quanto dois já tinham se formaram.

A escola é mantida com recursos esparsos e descontínuos, com financiamentos governamentais ou empresariais, através de leis de incentivo à cultura e parcerias estabelecidas com a Redes da Maré e com a Lia Rodrigues Companhia de Danças. A falta de garantia de financiamento perene e os desafios de desenvolver um trabalho de arte na Maré, território também marcado pela falta de segurança ${ }^{23}$ e habitado por famílias de baixa renda, obriga à Lia Rodrigues, sua equipe e Silvia Soter a avaliarem e repensarem suas estratégias de ação permanentemente. Lia Rodrigues fala de uma metodologia mutante, enfatizando que adaptar-se aos limites, às possibilidades e às oportunidades que se apresentam a manter uma escola de dança na Maré é condição para lá permanecer e garantir que o trabalho junto aos jovens continue. A rede solidária de instituições, artistas e professores nacionais e estrangeiros ${ }^{24}$ que se criou em torno do projeto também tem sido fundamental para ampliar as possibilidades de trocas e práticas para os jovens alunos.

O Núcleo 2 não tem como objetivo tornar-se um grupo profissional de dança: a prática de criação e apresentação de obras é entendida como parte importante do processo de formação. O primeiro trabalho do grupo, Exercício $M$, de Movimento e de Maré, foi entendido como um exercício e desde de sua estreia, em abril de 2013, apresentado apenas em contextos pedagógicos. Foi composto por solos e duos criados pelos integrantes do

23 O cotidiano do morador de favelas no Rio de Janeiro é marcado pela falta de políticas públicas de segurança. No Complexo de Favelas da Maré, há constantes enfrentamentos entre policiais e traficantes, mas também entre diferentes gangues de tráfico de drogas, e até mesmo invasões a casas de moradores por parte de policiais, num desrespeito evidente aos direitos humanos. O Boletim Direito à Segurança Pública na Maré 2019, publicado pela Redes da Maré, mostra que em 2019 os moradores da Maré enfrentaram 300 horas de operações policiais, 117 dias de tiroteios durante todo o ano, resultando em 34 mortes em operações policiais e 15 vítimas em disputas entre criminosos ligados ao tráfico de drogas.

24 Nestes anos, alguns intercâmbios internacionais se destacaram. Em 2013, os jovens do Núcleo 2 estiveram em intercâmbio com jovens da Académie de Danse da Ecoles Municipales Artistiques, de Vitry-sur-Seine, França. Em 2016, cinco estudantes participaram do Camping, um importante encontro de escolas e formações de dança no Centre National de la Danse - CND, Pantin, França. Em dezembro de 2016, participaram da primeira fase do intercâmbio com o Bachelor Danse de La Manufacture, em Lausanne, Suíça. Em abril de 2017, os estudantes do terceiro ano do Bachelor Danse desta escola suíça fizeram uma residência de um mês na Escola Livre de Dança da Maré. Também em 2016, quatro integrantes do Núcleo 2 foram selecionados para a audição para a turma de 2016-2019 de formação em dança contemporânea da escola belga P.A.R.T.S, em Bruxelas. No final da seleção, Gustavo Gláuber e Rafael Galdino ficaram entre os 44 candidatos escolhidos e ingressaram na escola belga. Em 2017 e 2018, os integrantes do Núcleo 2 participaram mais uma vez do Camping, em Paris. Em 2019, dois veteranos do Núcleo 2, Marllon Araújo e Luyd Carvalho, também foram aprovados para a P.A.R.T.S. 
grupo sob a orientação da coreógrafa e de sua companhia, a partir da releitura de um trecho de Aquilo de que somos feitos, obra de 2000 da LRCD. Algumas características da coreografia, como o uso da voz e do canto, as mudanças precisas de direção espacial e de dinâmica, a teatralidade e a temática política ${ }^{25}$ justificaram a escolha dessa peça do repertório para este primeiro exercício de releitura e de criação.

Já em 2015, os estudantes do Núcleo 2 trabalharam junto com os artistas da companhia por quatro meses, durante o início do processo de pesquisa que resultou, mais tarde, em Para que o céu não caia, espetáculo da LRCD que, já sem a presença dos jovens alunos, estreou em Hellerau, Dresden, Alemanha, em maio de 2016. Também em 2015, o Núcleo 2 participou de uma performance na Maré ligada à campanha Jovem Negro Vivo, da Anistia Internacional. Palestras, aulas de teoria e história da dança e discussões sobre assuntos diversos, como questões de gênero e sexualidade também fizeram e continuam fazendo parte do programa de ensino da escola.

Neste período de aprendizagem, a vida dos integrantes do Núcleo 2 passou por grandes transformações. São mudanças concretas como, por exemplo o ingresso na universidade pública, intercâmbios com outros jovens que os levam a viagens internacionais, mas há também a transformação em suas subjetividades, descrita por eles próprios em seus depoimentos ao longo dos últimos anos.

Escolhemos os relatos de alguns alunos do Núcleo 2 para ilustrar essas mudanças. Damos voz à L. T. e D. Os três entraram no Núcleo 2 na primeira audição, em 2012. Em 2018, L. e D. continuavam no grupo, já T. saiu em 2015 para poder se dedicar somente à universidade, mas nunca se afastou dos amigos que fez ali. L. e T. têm uma história similar de aproximação da dança, que começa com a participação num grupo amador na Igreja Batista do Parque União - uma das 16 comunidades do Complexo de Favelas da Maré. Em 2009, souberam das aulas com dançarinos da companhia de Lia Rodrigues e decidiram se inscrever. Até aquele momento nenhuma das duas conhecia Lia Rodrigues e nem tinha visto um espetáculo de dança contemporânea. Também tinham muito pouco contato com projetos artísticos, como relatou $\mathrm{T}^{26}$ : 
É uma coisa cultural, as pessoas de mais baixa renda, eu mesmo me incluo nisso, não têm uma formação em arte. Nas aulas de arte na escola, a professora dá uma folha e a gente rabisca. É só desenho. Não tem literatura, não vê cinema, a gente não tem essas noções. É algo que sempre me fizeram acreditar que era supérfluo. Só faz arte quem tem dinheiro, diziam. E muita gente aqui dentro da Maré tem esse tipo de pensamento até hoje porque é algo cultural.

Em 2011, assim que as L. e T. souberam que a Escola Livre de Dança da Maré seria inaugurada, se inscrevem nas aulas e ali começam a se preparar para a audição do Núcleo 2. Aprovadas, passaram a ver a dança como um projeto profissional de longo prazo. Desde 2014 T. cursa bacharelado em dança na Universidade Federal do Rio de Janeiro, enquanto a L. e D. ingressaram na mesma universidade em 2015.

Desde que os jovens começaram a conviver com a companhia, a assistir aos espetáculos, a conversar e debater com os dançarinos profissionais, o modo de verem a dança também mudou. Se no começo, a nudez nas peças de Lia Rodrigues chocava L., depois passou a ser natural, como ela descreveu:

\begin{abstract}
Eu não venho aqui só para dançar. A gente entrou de uma forma e saiu de outra, muito mais maduro. Também em relação aos próprios espetáculos da Lia, porque eu nunca tinha visto dança contemporânea e, de repente, vi gente nua no palco, aquilo me chocou muito, feriu a minha moral. Eu fiquei muito chocada, fiquei pensando nisso por semanas. Depois parei para analisar e pensei: por que ela colocou pessoas nuas no palco? Podia ser com roupa? Eu vi todos os trabalhos, porque houve uma maratona aqui [no Centro de Artes da Maré], vi Encarnado, Aquilo de que somos feitos, Formas Breves. O primeiro que vi foi Formas Breves ${ }^{27}$. Me lembro que a Amália [Lima] entrou nua e eu fiquei chocada em ver o semblante dela tratando aquilo como algo muito natural. $\mathrm{E}$ a Lia foi explicando para a gente o porquê disso tudo. E hoje vejo como algo natural. Foi realmente uma quebra de preconceito. Foi uma quebra de mim, de dentro para fora.
\end{abstract}

Já D. não é morador da Maré. Vive em Vila Isabel, bairro da Zona Norte do Rio de Janeiro. Ele começou a ter aulas de dança perto de sua residência em 2006, mas diz que só em 2012, quando passou a integrar o Núcleo 2, que iniciou seus "estudos intensivos de dança e artes no geral". Aos 25 anos, já na universidade, D. a valia os impactos de integrar o Núcleo 2 da Escola Livre de Dança da Maré:

Foi nesta formação que descobri minha verdadeira vocação para a dança, onde percebi que a arte que praticava não se tratava somente de reprodução de movimentos, mas, sim, de um movimento gigantesco que é capaz de mudar trajetórias, capaz de mudar 
e salvar muitas vidas. Com a formação no Núcleo 2 foi possível ver a minha mudança de pensamento em relação a minha vida e o que eu queria de fato para o meu futuro. Pude começar a formalizar e dar partida a meus objetivos como, por exemplo, ingressar na faculdade de dança. Pensar o meu lugar na sociedade através da arte se tornou uma questão de dever para mim. Me conscientizei do meu lugar e do meu papel para o compromisso com o próximo, me alimentando de cada experiência que adquiri com este tempo, minha visão política foi ampliada e passei a obter mais informação através da dança. Hoje posso dizer que a dança e toda a formação que carrego comigo até este presente momento foram essenciais para meu crescimento como ser humano.

\section{Trabalhos formativos}

Em 2017 e 2018, os veteranos do Núcleo 2 passaram por mais duas fortes experiências formativas, a partir da participação num trabalho de criação e numa remontagem. No primeiro semestre de 2017, Lia Rodrigues e Amália Lima - que está na LRCD desde 2000 e há mais de uma década é o braço direito da coreógrafa - comandaram um processo de criação a lado dos jovens, partindo de dois trabalhos da companhia realizados após a chegada à Maré: Pororoca, de 2009, e Piracema, de 2011, que, juntos, deram origem a Exercício $P$, de Pororoca e Piracema, apresentado no Centro de Artes da Maré em maio e junho de $2017^{28}$. Tanto Pororoca quanto Piracema têm como tema a ideia de viver junto. Pororoca é a palavra tupi para designar o fenômeno de encontro das águas do mar com as águas do rio. Tem barulho, agitação, ondas enormes, capazes de derrubar árvores, destruir margens e misturar águas. Já Piracema, que também vem do tupi, quer dizer a subida dos peixes no rio, contracorrente, para a desova. É uma subida sofrida, dolorosa, com muito esforço. Essas ideias centrais embalaram o trabalho do Núcleo 2, que não é uma remontagem propriamente dita, mas sim de uma transformação daqueles trabalhos concebidos no chão da Maré, o mesmo que vem abrigando os jovens dançarinos em sua formação e o mesmo de onde muitos deles vieram. A proposta não foi e nem resultou numa tentativa de repetição de movimentos por outros corpos, mas sim de uma inspiração que guiou a criação.

28 Do programa do trabalho, que estreou dia 25 de julho de 2017: "Para se formar em dança entendendo formação em um sentido mais amplo, indo além da preparação de um intérprete - é necessário em algum momento desta trajetória atravessar uma experiência de pesquisa e criação. Dez alunos do Núcleo 2 - Núcleo de Formação Continuada da Escola Livre de Dança da Maré mergulharam no repertório, especialmente nos espetáculos Pororoca (2009) e Piracema (2011), e em procedimentos de pesquisa de criação da Lia Rodrigues Companhia de Danças. A coreógrafa Lia Rodrigues, sua assistente Amália Lima e os artistas da companhia desenvolveram uma série de estratégias para que esse grupo de jovens experimentassem o material coreográfico e sobre este deixassem suas marcas. Como resultado, nasceu Exercício $P$, de Pororoca e Piracema, uma parte fundamental da formação em dança - atravessar uma experiência de pesquisa e criação." 
O processo não incluiu sessões de vídeos de Pororoca e Piracema. Alguns dos dez dançarinos haviam visto Pororoca, outros Piracema ao vivo, mas outros nem isso. A transmissão foi oral - por Lia Rodrigues e Amália Lima - trabalhando as ideias centrais das duas peças para criar novos mundos possíveis. L. um dos integrantes do grupo, relatou assim a concepção do Exercício P:

\begin{abstract}
Elas falaram da ideia do Pororoca, que era de uma linha onde todos transitam juntos, num espaço pequeno. E a ideia do Piracema, que era cada um criar um solo. A partir disso e de contagens dadas pela Lia, fomos autônomos para criar as coreografias entre a gente, para construir as transições. A Amália ajudou muito na qualidade dos movimentos, mostrando como é possível pensar em imagens que o movimento tem. Depois, na segunda parte, cada um deveria fazer um solo que representasse a si. A Lia perguntou o que era dança para cada um de nós, por que continuamos dançando. A ideia era mostrar quem somos nós através do movimento. Eu construí um pequeno solo, mostrei as relações com as aulas no Centro de Artes, o hip hop que me levou à dança e as experiências que mais me marcaram no Núcleo $2 .{ }^{29}$
\end{abstract}

Os dez intérpretes-criadores de Exercício $P$ deram novas vidas à Pororoca, mas e, sobretudo, à Piracema, que ganhou outras intensidades nos corpos e nas vozes dos jovens: em dez solos os bailarinos dançam e contam suas vidas, suas trajetórias na e com a dança. Diante da plateia, surge, uma a uma, a vida de jovens pobres das favelas do Rio de Janeiro, que sofrem diariamente com múltiplas violências, mas mesmo assim descobriram na arte um caminho e um objetivo. A dança se une à fala. São relatos que juntam dança e palavra. Cada um dos dez jovens intérpretes aproveita a chance para se desnudar na frente de seu público, mas, e sobretudo, para deixar claro como a dança e a arte foram capazes de transformar suas vidas. $\mathrm{E}$, em certas partes dos solos, os demais intérpretes se juntam à cena para fazer uma dança de conjunto ligada ao que está sendo dito.

Escolhemos aqui dois dos textos escritos e falados pelos bailarinos em Exercício $P$, de Pororoca e Piracema. 
K, moradora da Maré:

Essa é a minha mochila. Na minha mochila carrego tudo que acho necessário para o funcionamento do meu dia, às vezes para mais de um dia. Quando ponho a mochila nas costas e saio de casa, não sei ao certo quando volto. Tenho me sentido meio nômade ultimamente. Tenho muitas lembranças boas desse lugar (o Centro de Artes) e tenho saudades do que ainda não vivi. Mas tem uma em especial que gosto de partilhar, que é do dia anterior à audição para o Núcleo 2. Faço faculdade no Fundão, são trinta minutos de caminhada e normalmente vou andando. Passei pelo Centro de Artes para encontrar com a Luciana (Barros), que já era do Núcleo 2. Ela havia conseguido uma carona, e caronas são sempre bem-vindas. Quem oferecia a carona era a Eliana Sousa, diretora da Redes da Maré, uma ONG que atua na Maré há mais de dez anos. A Lia Rodrigues, diretora artística do Núcleo, também estava na carona. Nós ainda não nos conhecíamos, então começamos a conversar, Lia me perguntou quem eu era e o que estava fazendo no momento, eu respondi que trabalhava como secretária na Redes o dia inteiro e não estava dançando. Lia me falou de uma audição para o Núcleo 2, que aconteceria no dia seguinte e meio que me intimou a fazer a audição. Então eu fui, fiz a audição, e passei. Essa carona destinou os últimos três anos da minha vida. Pela escola eu pude conhecer dois lugares, a França e a Suíça. Conhecer esses lugares ampliaram minha visão de mundo. Me ajudaram a me entender melhor como brasileira, uma pessoa que vive de arte, mulher, negra e favelada. Me ajudou a entender melhor o que penso sobre dança. Isso tudo caminha junto para mim. A vida e a dança andam juntas, sem separação.

\section{L, também moradora da Maré, fecha a apresentação falando assim:}

Eu pensei em trazer um fogão, que colocar ele bem aqui dentro da nossa casinha. $E$ fazer um feijão daquele com alho, fresquinho, do primeiro dia. Para a gente comer junto. Mas aí eu pensei, não! Vai dar muito trabalho. Na verdade, eu penso muito, eu penso tanto que às vezes eu deixo de fazer uma coisa porque eu penso demais. Eu conheci esse espaço (o Centro de Artes da Maré) em 2009, eu tinha 17 anos, é, faz um tempinho. Eu lembro que no primeiro ano de Núcleo 2 nós tivemos uma professora chamada Carol Pedalino e ela dava uma aula tipo dança-teatro. E foi com essa aula que eu comecei a entender o que era estado de espírito, que meu cabelo era um estado de espírito, e que meu corpo falava de diversas formas. No segundo ano de Núcleo 2, tivemos a professora Ana Paula Kamozaki, e a Ana me deu um presente que foi a consciência corporal. E com a consciência corporal, eu comecei a perceber meu corpo, perceber que eu tinha buracos. Buracos de um corpo que não entra dentro do padrão da dança e nem da sociedade. Buracos de saudade da minha família. Eu comecei a perceber que todo mundo tem buraco. Que a moça que mora na rua do Centro de Artes ela tem um filho e um dia esse filho saiu na rua e o Caveirão entrou, essa criança levou um tiro e ficou com um buraco no peito. E essa mãe com um buraco de ausência e dor. As crianças que estudam nas creches da Maré têm um buraco de cultura e educação porque quando tem operação policial na favela os professores não podem entrar para dar aula. Então eu comecei a pensar em buraco e articulação, articulação e buraco e linha. Na favela não tem só baile funk, tem a feira de fruta da Teixeira, do Parque União. Na favela tem gente que sonha com lugares como esse aqui, o Centro de Artes. Olha ali tem um buraco, um buraco que gira. Eu conheci a dança contemporânea aqui nesse lugar e até hoje estamos caminhando juntas. Até onde eu não sei. Mas de uma coisa eu sei que por um momento eu tive amigos aqui, que seguram o meu céu. E hoje nós juntos queremos agradecer a presença de todos vocês aqui. Muito obrigada. 
Em fevereiro de 2018, a turma de veteranos do Núcleo 2 deu início a um outro projeto idealizado por Lia Rodrigues, desta vez em parceria com a coreógrafa francesa Maguy Marin. Tratou-se da remontagem do espetáculo May B, de 1981, tida como obra-prima de Maguy, e presenteada por ela ao Núcleo 2. Nomeada de De Ste Foy-lès-Lyon à Rio de Janeiro, May $B$ à la Maré, une fraternité, a remontagem começou a ser feita em fevereiro de 2018 por uma assistente da Maguy Marin, Isabelle Missal, e pela brasileira Amália Lima. Depois o trabalho foi finalizado no espaço dirigido pela coreógrafa, em Lyon, França, em fim de março, com a presença de Maguy Marin e de Lia Rodrigues, que havia feito parte do elenco da montagem original. A estreia aconteceu em Lyon e, em seguida, os dez integrantes do Núcleo 2 fizeram uma temporada por cinco cidades francesas, incluindo Paris.

May $B$ é uma peça em que dez personagens que fogem de um padrão (tem mulher acima do peso, idosos, gente torta, com as faces monstruosas, esbranquiçadas, e com roupas imundas), inspirados no teatro do absurdo de Samuel Beckett, parecem buscar sentido para a vida. Cenas cômicas dividem o palco com momentos trágicos e outros líricos. Há dança, movimentação teatral, frases incompreensíveis, pequenas cantorias, caretas, gritos. Existe também um forte traço pedagógico na opinião de sua autora, Maguy Marin:

\footnotetext{
É uma peça para profissionais que funciona também como formação para jovens. Oferece diferentes ferramentas artísticas ao intérprete, que tem que ser ao mesmo tempo parte de um grupo, mas encontrar sua projeção individual. Há um trabalho muito grande e delicado sobre ritmo, musicalidade, precisão. E o que é mais especial é que May $B$ pode ser aperfeiçoada depois de aprendida, é como sempre pudesse melhorar. ${ }^{30}$
}

A tensão nos corpos dos dez jovens da Maré, explícita na estreia em Lyon, deu lugar a uma dose certa de adrenalina em Paris, dez dias depois. Ajudou terem passado antes pelo grande teatro de Cergy-Pontoise, para 600 pessoas, onde a maioria da plateia era formada por estudantes jovens, e um passeio a lazer pela Disney de Paris. Chegaram ao Centquatre, palco da capital francesa, com mais confiança. E ali tiveram a segurança para se manifestarem politicamente. Nos agradecimentos depois de cada apresentação, levantaram cartazes com palavras de ordem e um retrato da vereadora carioca Marielle Franco, assassinada em 14 de março de 2018, e 
que, assim como eles, foi criada na favela da Maré. Um dos integrantes do Núcleo 2, L., explicou a decisão do grupo de se expor politicamente:

Decidimos que neste momento tão difícil do Brasil, era hora de mostrar nossas posições políticas. Nos posicionamos contra o fim da profissão de artista, sobre a prisão do Lula e sobre a Marielle, cuja morte nos afetou muito e que continua sem resposta. ${ }^{31}$

\section{Considerações finais}

Por esses relatos constata-se que, para os jovens, a experiência de integrar o Núcleo 2 ultrapassa o que recebem como uma formação técnica em dança. A presença de Lia Rodrigues e de sua companhia na Maré, a criação do Centro de Arte da Maré e a existência da Escola Livre de Danças da Maré, as viagens e contatos com artistas de diferentes formações e nacionalidades alargou a visão de arte, de dança que traziam e os estimulou a lutar por seus desejos e direitos, para além da dança.

É esta corressonância entre dança e seus lugares, entre corpos e chão, na dimensão da coreopolítica, que acreditamos estar no encontro de Lia Rodrigues, coreógrafa e pedagoga construtora, com a favela da Maré, na experiência da companhia com aquele terreno, seus moradores e o seu entorno. Nestes anos na Maré, a artista e sua equipe vêm tentando penetrar nas multicamadas daquele chão em vez de alisá-lo. Ou ao menos vem tentando desvendar essas camadas, no seu dia a dia ali, de trabalho em trabalho, mas também na criação de uma escola de dança e de um grupo de formação intensiva em dança, como o Núcleo 2.

Ao se transferir para a Maré, Lia Rodrigues e sua equipe buscam responder à pergunta básica de um projeto coreopolítico ${ }^{32}$ : "Em que chão quero dançar?", posicionando-se claramente ao escolher uma favela, com toda a sua história, restrições, limitações, contradições e intensidades. O chão que a artista constrói na Maré é também lugar de encontro, de troca de saberes e de formação em dança e através da dança.

E, a partir de então, com suas criações, na fundação da Escola Livre de Dança da Maré e do Núcleo 2, tem respondido à outra questão coreopolítica: "Que chão é este em que danço? 


\section{Bibliografia:}

Boletim Direito à Segurança Publica na Maré. Redes de Desenvolvimento da Maré, 2019. https://www.redesdamare.org.br/media/downloads/arquivos/BoletimSegPublica 2019.pdf. Acesso em 25 jun. 2020.

CHOPIN, Marie-Pierre. Pédagogues de la danse: transmission des savoirs et champ choéographique, Paris: Éditions Fabert, 2015.

LEPECKI, André. Coreopolítica e coreopolícia in: ILHA Revista de Antropologia, Universidade Federal de Santa Catarina, Programa de Pós-Graduação em Antropologia Social, v. 13, n. 1. Florianópolis: UFSC PPGAS, 2012.

LEPECKI, André. Exhausting Dance: Performance and the Politics of Movement. London and New York: Routledge, 2006.

LIMA, Daniella. Corpo, política e discurso na dança de Lia Rodrigues. Rio de Janeiro: UniverCidade Editora, 2007.

PAVLOVA, Adriana. Dança e Política: Movimentos da Lia Rodrigues Companhia de Danças na Maré. Dissertação, Universidade Federal do Rio de Janeiro, Rio de Janeiro, 2015. Inédita.

SILVA, Eliana Sousa. Testemunhos da Maré. Rio de Janeiro: Editora Aeroplano, 2012.

SOUZA E SILVA, Jaílson; BARBOSA, Jorge Luiz e FAUSTINI, Marcus. O novo carioca. Rio de Janeiro: Mórula Editorial, 2012.

Recebido em 16 de julho de 2020 e aceito em 01 de março de 2021.

Este é um artigo publicado em acesso aberto sob uma licença Creative Commons (cc)) Br 